\title{
IGOR KĄKOLEWSKI
}

Centrum Badań Historycznych PAN, Berlin

\section{NIGDY NIEUMIERAJĄCE CIAŁO PAŃSTWA, CZYLI O TRWAŁOŚCI TOPOSU (RE-)BORN STATEHOOD W EUROPEJSKIEJ KULTURZE POLITYCZNEJ}

For the King has in him two Bodies, viz., a Body natural, and a Body politic. His Body natural (if it can be considered in itself) is a Body mortal, subject to all infirmities that come by Nature or Accident, to the Imbecility of Infancy or old Age and to the like Defects that happen to the natural Bodies of other People. But his Body politic is a Body that cannot be seen or handled, consisting of Policy and Government, and constituted for the Direction of the People, and the Management of the public weal, and this Body is utterly void of Infancy, and old Age, and other natural Defects and Imbecilities, which the Body natural is subject to [-- $]^{1}$.

Na wywołany w tegorocznej ankiecie „Kwartalnika Historycznego” problem rozkładu i upadku państwowości pragnę spojrzeć z trzech perspektyw: filozofii politycznej, antropologizującej oraz historycznej. Perspektywy te wzajemnie przenikają i uzupełniają się zwłaszcza w badaniach nad historią idei, ideologii państwowych oraz ewoluujących w dziejach wyobrażeń o państwie i formach jego ustroju. Przy tym

${ }^{1}$ Fragment ekspertyzy angielskiego prawnika Edmunda Plowdena z początku lat sześćdziesiątych XVI w., cyt. za: E.H. Kantorowicz, The King's Two Bodies. A Study in Medieval Political Theology, Princeton 1957, s. 7 n. W filozofii politycznej wczesnej epoki nowożytnej sformułowania o wyższości natury ciała państwa nad fizycznym ciałem monarchy można znaleźć u Erazma z Rotterdamu, a na gruncie polskim podobny sens kryje się w korespondencji wojewody sandomierskiego Piotra Zborowskiego z lipca 1572 r.: „królowie polscy marli y mrzeć muszą, ale [przodkowie nasi - I.K.] tak rozumieli, że RP ich była y bydź ma nieśmiertelna", cyt. za: C. Backvis, Główne tematy polskiej myśli politycznej w XVI wieku, w: idem, Szkice o kulturze staropolskiej, Warszawa 1975, s. 492. 
w moim szkicu będą mnie bardziej interesować wybrane aspekty historii ustrojowej $\mathrm{w}$ długim trwaniu oraz meandry tzw. kultury i polityki pamięci niż społeczno-polityczne mechanizmy anarchizacji i rozpadu struktur państwowych. Odchodząc od ściśle politologicznych definicji failed statehood, dotyczących sytuacji geopolitycznej we współczesnym świecie oraz dominujących w dyskursie o kolonializmie i konsekwencjach postkolonializmu ${ }^{2}$, chciałbym poddać refleksji z jednej strony częstotliwość zjawiska zaniku państwowości w rozumieniu redukcji suwerenności państwa, z drugiej zaś - przywołany w tytule - konstrukt „odradzania” konkretnych państwowości w Europie. Kwestię modelu failed statehood stosowanego przez politologów w odniesieniu do zjawiska rozpadu struktur państwowych na początku XXI w. zwłaszcza w niektórych regionach Afryki i Bliskiego Wschodu, użytecznego również dla historyka zajmującego się wczesnonowożytnymi dziejami Polski do analizy procesów anarchizacji życia politycznego w dawnej Rzeczypospolitej - wypadnie odłożyć na inną okazję.

Jednym z fundamentalnych wyobrażeń o państwie jako takim wydaje się być przekonanie o jego trwałości wykraczającej ponad łańcuch wielu pokoleń ludzi w nim żyjących. Niezależnie od formy ustrojowej - monarchicznej czy republikańskiej - ideologemem legitymizującym funkcjonowanie państw i nadającym sens ich istnieniu w odczuciu rządzących i rządzonych jest - inaczej niż w przypadku egzystencji ludzkich jednostek i ich ciał - wiara w „nigdy nieumierające ciało państwa” ${ }^{3}$.

2 Termin failed state używany jest w kontekście dyskursu nad kolonializmem i jego konsekwencjami, we współczesnej politologii zaś przede wszystkim na określenie sytuacji dysfunkcji struktur państwowych charakteryzowanych przez: utratę przez aparat państwowo-administracyjny kontroli nad terytorium państwa, zanik „legalnego monopolu stosowania przemocy" (w sensie Weberowskim), wysoki stopień pandemicznej korupcji oraz zagrożenie wewnętrznymi konfliktami i odśrodkowymi działaniami, niemożność realizacji decyzji politycznych i świadczenie usług protekcyjnych dla obywateli przez władze, a także niemożność wchodzenia w pełnoprawne interakcje z innymi podmiotami społeczności międzynarodowej. Biorąc pod uwagę te właśnie symptomy kryzysu władzy państwowej, amerykańska organizacja obywatelska Fund for Peace (FFP) ogłasza coroczny Fragile States Index, wskazując poziom destabilizacji i anarchii w poszczególnych państwach współczesnego świata. Jednak w dyskusjach politologicznych ciągle powraca pytanie o mierzalność failed staehood oraz o to, które organizmy państwowe można zakwalifikować jako w pełni upadłe. $Z$ bogatej literatury przedmiotu zob. m.in.: C.T. Call, The Fallacy of the „Failed State”, „Third World Quarterly” 29, 2008, 8, s. 1491-1507, a także podsumowująco J. Grävingholt, S. Ziaja, M. Kreibaum, State fragility. Towards a multi-dimensional empirical typology, Bonn 2012, https://www.die-gdi.de/ uploads/media/DP_3.2012.pdf (dostęp: 15 VII 2017).

${ }^{3}$ Ideologem to wyobrażenie (wartościująca koncepcja) będące elementem składowym ideologii, czasami funkcjonujące autonomicznie i wprowadzane do rozmaitych 
Przekonanie odwrotne, pesymistyczne założenie, że państwo jest bytem ontologicznie ograniczonym w czasie, podlegającym procesom rozkładu i upadku, jest w sferze oficjalnych wyobrażeń i ideologii państwowych $z$ reguły bądź tabuizowane, bądź instrumentalizowane dla celów demagogicznej propagandy. Jednak nawet na poziomie refleksji z zakresu filozofii politycznej koncepcje naturalnej i nieuchronnej „korupcji” każdego typu ustroju i państwa - jak w przypadku teorii cyklicznej ewolucji typów władzy Polibiusza i Niccola Machiavellego ${ }^{4}$ - są rzadkie.

Bardziej typową reakcją politycznych filozofów na różnego rodzaju zagrożenia i kryzysy państwa jest aksjologiczna reakcja „Augustiańska”. Polega ona na poszukiwaniu idealnego ładu społecznego i sytemu ponadczasowych, uniwersalnych wspólnotowych wartości w opozycji do dominującego porządku opartego na wartościach niedoskonałych czy wręcz wadliwych. Święty Augustyn niedługo po najeździe Rzymu przez Wizygotów (410) i wywołanego nim szoku mieszkańców imperium rzymskiego w De civitate Dei dowodził, że w sytuacji zagrożenia i upadku „państwa doczesnego" (civitas terrena) ostatecznie zatryumfuje „państwo Boże” (symboliczna Nowa Jerozolima). Granica między obu państwami miała wypływać z dwóch postaw człowieka: „życia według ciała” lub „życia według ducha”. Charakterystyczne dla każdego państwa doczesnego (symbolicznego Babilonu) wady - wedle autora De civitate Dei - powstają z ciała, gdyż, „postępować według zasad czysto ludzkich znaczy to samo, co być cielesnym, gdyż przez ciało, to jest przez część człowieka, rozumie się człowieka” (ks. XIV, 4.2). Z kolei „życie według ducha” wymagało, zwłaszcza od chrześcijan, poświęcenia większej uwagi sprawom duchowego, mistycznego, niebiańskiego miasta-państwa niż kwestiom polityki. Augustiański schemat myślenia oparty na opozycji „dwóch państw”, w pełnym średniowieczu wzbogacony przez św. Tomasza z Akwinu o arystotelesowską klasyfikację ustrojów państw i ich degeneracji, dominował w europejskiej filozofii politycznej do wczesnej epoki nowożytnej.

ideologii lub uporządkowanych systemów wyobrażeń uwarunkowanych politycznie i społecznie. Pojęcie używane głównie w literaturoznawstwie i teorii literatury badającej społeczno-kulturowe konteksty tekstów literackich, naukowych, propagandowych etc.

${ }^{4}$ Machiavelli w Rozważaniach nad pierwszym dziesięcioksięgiem historii Rzymu Liwiusza wszystkim ustrojom przypisywał, podobnie jak Polibiusz, wbudowaną w nie tendencję do degeneracji spowodowaną pogłębiającymi się w miarę upływu czasu: bezczynnością społeczeństwa, nierównością społeczną oraz dążeniem do zagarnięcia przez rząd coraz szerszych prerogatyw władzy. Te trzy czynniki degenerują „materię” społeczną, przyczyniając się do utraty przez społeczeństwa zbiorowej „cnoty”, ostatecznie prowadząc do szeroko pojętej „korupcji” i rozkładu państwa, zob. obszerniej I. Kąkolewski, Melancholia władzy. Problem tyranii w europejskiej kulturze politycznej XVI stulecia, Warszawa 2017, s. 83 n. 
Cum grano salis można powiedzieć, że do schematu dialektycznej opozycji „dwóch państw” (tym razem jednak na gruncie filozofii materialistycznej, nie zaś idealistycznej) zbliżyła się w połowie XIX w. marksowska krytyka państwa kapitalistycznego oraz koncepcja komunizmu jako finalnego stadium rozwoju ludzkości. Miał on zapewnić „skok do królestwa wolności" ', definiowanego w opozycji do wolności gloryfikowanych przez liberalizm. Z kolei pod koniec XX w., tym razem w sytuacji upadku państw funkcjonujących w oparciu o miazmaty komunizmu, podobny schemat myślenia - choć à rebours, bo w oparciu o pochwałę totalnie krytykowanych przez Karola Marksa wolności gospodarki rynkowej odnaleźć można w twierdzeniach Francisa Fukuyamy o tryumfie absolutyzowanego przezeń sytemu demokracji liberalnej jako „końcu historii" ${ }^{\circ}$. Smutne doświadczenia początku XXI w. wskazują, że i ten system ustrojowy nie musi się okazać bynajmniej finalnym, najdoskonalszym i najbardziej uniwersalnym dla ludzkości i może przechodzić momenty wzlotów i upadków. Co więcej, aktualna sytuacja międzynarodowa po fali interwencji militarnych i nieudanych prób demokratycznych rewolucji w Afryce Północnej i na Bliskim Wschodzie, których konsekwencją jest fenomen definiowany przez współczesną politologię mianem failed statehood, zdaje się przypominać o gorzkiej konstatacji, będącej jednym z podstawowych lejtmotywów wczesnonowożytnej filozofii politycznej, o anarchii jako zjawisku niebezpieczniejszym od tyranii ${ }^{7}$.

${ }^{5}$ A. Walicki, Marksizm i skok do królestwa wolności. Dzieje komunistycznej utopii, Warszawa 1996.

${ }^{6}$ F. Fukuyama, Koniec historii, Poznań 1996 (oryg. ang. 1992).

${ }^{7}$ Konstatacja ta stanowiła jeden z podstawowych elementów wczesnonowożytnej refleksji filozoficzno-politycznej, który określam jako „syndrom potrójnego lęku”, składający się z horror anarchiae, horror mutationis oraz horror czy raczej contemptus plebei: „Zarówno u zwolenników bardziej kategorycznego sposobu myślenia w biało-czarnych kategoriach (np. Erazm z Rotterdamu, Luter), jak i bardziej relatywizującego (Bodin, Lipsius) pobrzmiewają idee scharakteryzowane w następującej maksymie: «Jest rzeczą lepszą ścierpieć 100 lat tyranii, niż musieć przeżyć jeden dzień wojny domowej» (Le Jay). Ów horror anarchiae wypływał nie tylko z negatywnych doświadczeń spowodowanych ciągłymi wojnami religijnymi rozsadzającymi państwo, lecz także z typowej dla epoki przed wybuchem Wielkiej Rewolucji Francuskiej konserwatywnej postawy: «Sama zmiana rodzi niesprawiedliwość i tyranię» (Montaigne). Można ją określić mianem horror mutationis - lękiem przed zmianami wypływającym z dominacji w mentalności politycznej ery przedrewolucyjnej i preindustrialnej tradycji jako wartości najwyższej (w sensie: im «starożytniejsze» prawa i instytucje, tym doskonalsze). Z obydwoma lękami ściśle związany był contemptus plebei - odziedziczona po greckim antyku pogarda wobec motłochu i jego rządów mających przybierać charakter tyranii wielogłowej: demokracji czy też ochlokracji - rządów ubogiej większości obywateli", I. Kąkolewski, Melancholia władzy, s. 416. 
Spróbujmy spojrzeć na kwestię państwa z perspektywy antropologizującej, powracając do przednowoczesnej figuratywnej wizji jego konstruktu jako „ciała” - powszechnej metafory państwa od starożytności aż po XVII w. Mimo że przytoczona na początku tego eseju koncepcja „nigdy nieumierającego ciała króla” oddalała się od Augustiańskiej opozycji „dwóch państw” i została sformułowana dopiero w połowie XVI w., to jej elementy obecne były również w średniowiecznej chrześcijańskiej „teologii władzy”, jak przedstawił to w swej klasycznej pracy Ernst Kantorowicz, a także we wcześniejszych epokach, w których przeważały monarchiczne formy państwowości. Stąd też typowe dla ideologii władzy państw monarchicznych próby deifikacji rządzących nimi jednostek lub dynastii, tworzenia państwowych religii bądź przynajmniej legitymizacji doczesnych rządów boską sankcją, w celu zapewnienie ciągłości władzy. W chrześcijańskiej tradycji służyć temu miała również topiczna figura „władcy-bogowie”, którą starano się uzasadnić autorytetem Pisma Świętego, odwołując do fragmentu Księgi Psalmów (82, 6): „Ja rzekłem jesteście bogami". W XVII stuleciu porównanie władcy-bogowie stało się jednym ze sloganów epoki klasycznego absolutyzmu ${ }^{8}$.

Z kolei w epoce nowoczesności, która po oświeceniu odziedziczyła metaforę państwa jako „maszyny”, w XIX w. zaś wytworzyła konstrukt „państwa narodowego” oraz ideologie nacjonalizmów, istotną rolę $\mathrm{w}$ absolutyzacji państwowości odegrała heglowska koncepcja państwa jako dobra absolutnego - ,jako boskiej idei istniejącej na ziemi”. W formie zwulgaryzowanej podobny kierunek myślenia można odnaleźć w XX w. w reżimach totalitarnych i autorytarnych, w swych programach ideowych podkreślających nadrzędność bytu państwowego nad interesem jednostkowym oraz przypisujących państwu atrybut jeśli nie ponadczasowości, to przynajmniej trwania w długim, nieokreślonym horyzoncie czasowym.

$\mathrm{Z}$ antropologizującego punktu widzenia trzeba podkreślić istotną rolę w legitymizacji władzy państwowej rozmaitego rodzaju mitów fundacyjnych, łączących np. wątek genezy danej państwowości z początkami dominującej w niej religii lub mitów przedstawiających odrodzenie państwa niczym „Feniksa z popiołów”. Podobną funkcję legitymizującą pełniły też koncepcje kontynuacji państwowości po okresie jej upadku i jej „przeniesienia” (translatio) na nowo powstałe organizmy państwowe. Kreujące je dawne dziejopisarstwo (i nowoczesna historiografia), których

${ }^{8}$ M. Bloch, Królowie cudotwórcy. Studium na temat nadprzyrodzonego charakteru przypisywanego władzy królewskiej zwłaszcza we Francji i w Anglii, Warszawa 1998 (oryg. franc. 1983), s. $291 \mathrm{n}$. 
celem była (i jest) międzygeneracyjna „translacja pamięci” o przeszłości (tak w formie zmitologizowanej, jak i naukowej), pozostają ważnym instrumentem kształtowania tożsamości grupowych i państwowych. Ich istotnym elementem jest przekonanie o konieczności ciągłości i trwałości państwowości, do której przynależy dana wspólnota. W tej sytuacji zarówno przednowocześni dziejopisarze, jak i nowocześni historycy często byli i są „zakładnikami” systemów państwowych wartości i ideologii, prezentując (lub mitologizując) w swych dziełach narodziny, upadek i kontynuację danej państwowości.

Tymczasem prosty ogląd przeszłości przez historyka za pomocą jego metody poznawczej świadczy o czymś przeciwnym. Zdaje się potwierdzać raczej pesymistyczną teorię Polibiusza i Machiavellego (obaj byli przede wszystkim historykami) o nieuchronności fazy „korupcji” w cyklicznej ewolucji ustrojów i państw: w nieunikniony sposób stan rozkładu i upadku następuje po fazie wzrostu i stabilizacji. Abstrahując od antycznych władztw Bliskiego Wschodu, wśród współcześnie istniejących państw swoistym unikatem długowieczności wydaje się trwająca od ponad 20 stuleci imperialna państwowość Chin, do której trwałości przyczynił się system wartości konfucjanizmu z jego dążeniem do zbudowania idealnego porządku społecznego. Historia współcześnie istniejących państw na kontynencie europejskim ma krótszą metrykę.

Banalna, lecz trudna do podważenia z historycznej perspektywy jest konstatacja, że państwa i imperia po okresie wzrostu, konsolidacji i kryzysu upadały. Upadek samodzielnej państwowości przyjmował jednak różne scenariusze. Jednym z najbardziej uniwersalnych było wchłonięcie jednego organizmu państwowego przez inny poprzez podbój i zawłaszczenie jego terytorium. W przypadku historii Polski przykładów dostarczają rozbiory dawnej Rzeczypospolitej u schyłku XVIII w., często i nader subiektywnie postrzegane w kulturze pamięci Polaków jako zjawisko unikalne.

Innym bardziej „miękkim” scenariuszem była redukcja „suwerenności” jednego państwa przez inne. Termin „suwerenność” wprowadzony został do języka politycznego przez Jeana Bodina dopiero w drugiej połowie XVI w. Zgodnie z Bodinowską definicją (odrzucającą zjawisko podzielonej suwerenności jako contradictio in adiecto), a także w nowoczesnych, dziewiętnastowiecznych kategoriach myślenia o „państwach narodowych" jesteśmy skłonni przeciwstawiać zbyt ostro kwestie pełnej i niepełnej suwerenności państwowej, asocjując tę ostatnią z brakiem niepodległości narodowej. W przypadku dziejów Polski na takim sposobie myślenia ważą nasze traumy rozbiorowe. Tymczasem „miękkie” i rozciągnięte w czasie procesy ograniczenia i zaniku państwowości poprzez 
stopniową redukcję suwerenności były zjawiskiem równie częstym, jeśli nie częstszym niż dramatyczne, "twarde” scenariusze upadku państw wskutek podboju i aneksji. Przykładów dostarczają tutaj rozmaite formy uzależniania przez imperium Romanum sąsiednich państw-miast lub protopaństw plemiennych (w formule: socii lub foederati), a w późniejszych dziejach, od średniowiecza aż do epoki nowożytnej, losy unii personalno-dynastycznych i realnych.

Ograniczmy perspektywę refleksji, inspirowanych po części znakomitą książką Roberta Frosta ${ }^{9}$, do ostatniego tysiąclecia dziejów państw europejskich. W sytuacji państwa monarchicznego w epoce średniowiecza i nowożytności zwłaszcza unie personalne i dynastyczne wydawały się być rozwiązaniem naturalnym i trwałym. Nawet jeśli po dłuższym czasie dochodziło do rozpadu unii personalnej kilku państw, to i tak niektóre z nich natychmiast unię odnawiały, mimo że związki unijne, zwłaszcza w dłuższym okresie ich trwania, mogły prowadzić do faktycznej redukcji lub zaniku struktur i odrębności państwowych słabszego członu unii. Tak stało się po rozpadzie duńsko-szwedzko-norweskiej unii kalmarskiej (1397-1523), gdy Dania z Norwegią pozostały w związku in persona regis przez następne stulecia aż do $1814 \mathrm{r}$. W tym czasie rola polityczna Norwegii, mimo zachowania odrębnego systemu prawnego, ulegała jednak zanikowi, zwłaszcza po likwidacji norweskiej Rady Królewskiej w 1536 r., a centrum władzy przesunęło się do Kopenhagi. Z kolei po niespełna trzymiesięcznym okresie niepodległości w 1814 r. wskutek szwedzkiej inwazji Norwegia musiała przystąpić do unii personalnej ze Szwecją. Pozbawiona możliwości prowadzenia samodzielnej polityki zagranicznej, tym razem zachowała jednak odrębną konstytucję i hierarchię urzędów państwowych, wybijając się na pełną suwerenność dopiero po referendum w $1905 \mathrm{r}$.

Mimo formalnego zachowania odrębnych struktur państwowych (i stanowo-prawnych) w ramach unijnych związków, faktycznie często dochodziło do przesunięcia centrum władzy (monarszego dworu oraz instytucji państwowych z nim związanych) do jednego z państw, a wskutek tego peryferializacji drugiego oraz ograniczenia jego suwerenności. W konsekwencji mogło to prowadzić do likwidacji odrębności słabszego członu unii i pełnej konsolidacji struktur obu państw. Przykładem

${ }^{9}$ R.I. Frost, The Oxford History of Poland-Lithuania, t. 1: The Making of the Polish-Lithuanian Union 1385-1569, Oxford 2015; por. też moje uwagi w I. Kąkolewski, „Jedno nierozdzielne i nieróżne ciało" Rzeczypospolitej Obojego Narodu - o metaforyce "wcielenia” $i$ „ciała” w polsko-litewskich dokumentach unijnych, w: Od Horodła do Horodła. Unia horodelska - dzieje i pamięć (1413-2013), red. I. Kąkolewski, P. Kondraciuk, M. Kopczyński, Zamość-Warszawa 2013, s. 31-44. 
takiego właśnie rozwoju jest wykształcona na przełomie XV i XVI w. dynastyczno-personalna unia królestw Kastylii i Aragonii - w skład tej ostatniej wchodziły też połączone z nią wcześniej unią personalną królestwo Walencji oraz Katalonia. W ramach zjednoczonego królestwa Hiszpanii Aragonia przez następne dwa stulecia nominalnie zachowała odrębność ustrojową, z własnymi kortezami i sądownictwem. Z czasem uległa jednak dominacji Kastylii, silniejszej politycznie i gospodarczo, głównie z powodu monopolu na eksploatację zamorskich kolonii. Ostatecznie dekrety Nueva Planta z lat 1707-1716 doprowadziły do likwidacji odrębności Korony Aragonii, a wraz z nią także Walencji i Katalonii, kończąc w dziejach Hiszpanii epokę tzw. polisynodii. Wydane wówczas regulacje prawne, ograniczając autonomię sądowniczą, a nawet odrębności w urzędowym języku, przenosiły prerogatywy Rady Państwa wyłącznie na Radę Kastylii, a utworzone wspólne dla obu królestw stanowe kortezy w okresie rządów absolutystycznych do początku XIX w. de facto przestały odgrywać jakąkolwiek rolę.

Pewnych paraleli dostarcza też ponad czterechsetletnia ewolucja związków unijnych - od unii personalnej do realnej (ustrojowej) - Korony Polskiej z Wielkim Księstwem Litewskim oraz Królestw Anglii i Szkocji. Węzły polsko-litewskich unii (licząc od aktu w Krewie w 1385 r.) okazały się prawie tak trwałe jak angielsko-szkockie (licząc od unii Dwóch Koron w 1603 r.) - poza tym, że te ostatnie w zmienionej formule trwają do dziś (jak długo jeszcze?). Mimo zachowania pewnych odrębności zarówno Litwa od unii realnej w 1569 do 1791 r., a także Szkocja od unii parlamentarnej w 1707 aż do 1999 r., okazały się słabszymi członami w unijnych konfiguracjach. Powstałe w ich wyniku federacyjne struktury ustrojowe zarówno we wczesnonowożytnej Rzeczypospolitej, jak i Wielkiej Brytanii ulegały z upływem czasu procesowi stopniowego zaniku złożoności organizmów, przy jednoczesnym nasileniu tendencji unifikacyjnych, których realizacja nie zawsze była jednak prosta. Zapisy Konstytucji 3 maja, wprowadzając bardziej unitarny model państwa, spotkały się z szybką reakcją w postaci aktu Zaręczenia Wzajemnego Obojga Narodów z 20 października 1791 r., gwarantującego dwuczłonowy model federacyjny Rzeczypospolitej i ograniczoną odrębność ustrojową Wielkiego Księstwa. Pytanie, która z tendencji - unitarności czy federalnego dualizmu - wzięłaby górę, gdyby państwa polsko-litewskiego nie spotkały rozbiory, należy do dziedziny historii alternatywnej.

Z kolei w przypadku Wielkiej Brytanii po nasileniu tendencji federalistycznych od schyłku XX w. do głosu doszła tendencja decentralizacyjna $\mathrm{w}$ formie tzw. dewolucji, tj. przeniesienia kompetencji $\mathrm{z}$ organów 
centralnych na regionalne. Po zorganizowanym w 1997 r. w Szkocji referendum dewolucyjnym i uchwaleniu Scotland Act rok później, nowo utworzony parlament szkocki otrzymał prerogatywy legislacyjne we wszystkich kwestiach, które nie zostały zarezerwowane dla parlamentu brytyjskiego, jakkolwiek Westminster zatrzymał prawo do zawężenia lub poszerzenia zakresu uprawnień szkockiej legislatywy. W ten sposób referendum i akt dewolucyjny przypieczętowały proces odzyskiwania części suwerenności przez Szkocję jako członu Zjednoczonego Królestwa. Mimo to, jak widać po rezultatach referendum z 2014 r. w sprawie niepodległości Szkocji, za którą opowiedziało się ponad 44 proc. uczestników, szkocka dewolucja (zwłaszcza w obecnej sytuacji brexitu) nie wyklucza nasilenia tendencji separatystycznych, których celem jest odrodzenie w pełni suwerennej państwowości szkockiej.

Podobny wzrost separatyzmu obserwujemy obecnie w hiszpańskiej Katalonii, której regionalny parlament przyjął w 2013 r. deklarację suwerenności, w 2015 r. zaś około 80 proc. uczestników katalońskiego referendum opowiedziało się za niepodległością. Wreszcie w ostatnim referendum (1 X 2017) aż 90 proc. głosujących (przy frekwencji wynoszącej jednak tylko 43 proc. uprawnionych) głosowało za niepodległością Katalonii. Wszystkie trzy akty zostały unieważnione przez władze centralne $\mathrm{w}$ Madrycie. W reakcji na rezultaty ostatniego referendum zdecydowały się one na rozwiązanie regionalnych władz, a także wszczęcie postępowania karnego wobec członków katalońskiego rządu, oskarżając ich o działalność wywrotową na szkodę Królestwa Hiszpanii. Wyznaczonym przez Madryt na 21 grudnia 2017 r. wyborom do regionalnego parlamentu towarzyszyła zażarta kampania, w której zwolennicy niepodległości sięgali również chętnie do arsenału argumentów historycznych, odwołując się przy tym często do dziejów średniowiecznej Katalonii oraz wczesnonowożytnych tradycji katalońskiej autonomii ${ }^{10}$.

Jak widać, struktury państwowe powstałe w wyniku unii, a następnie zaniku złożoności organizmów przy nasileniu tendencji unifikacyjnych, nawet po kilku stuleciach mogą znaleźć się w poważnym kryzysie. Jego konsekwencją może być odzyskanie pełnej niepodległości przez organizmy państwowe, które wskutek niegdysiejszych unii zatraciły swą odrębność, stając się egzemplifikacjami jednego z „miękkich” scenariuszy zaniku/upadku odrębnej państwowości. Prawdopodobieństwo takiego scenariusza odrodzenia zanikłych wcześniej państw w Europie zwiększa przybierająca na początku XXI w. nowa fala nacjonalizmów, z których

10 Zob. Opinion. Catalan nationalists transfixed on the past - http://www.dw.com/en/ opinion-catalan-nationalists-transfixed-on-the-past/a-41039608 (dostęp: 28 XI 2017). 
część wyrasta z ambicji regionalnych odwołujących się do dawnych tradycji państwowych (np. Flamandia, Lombardia) ${ }^{11}$.

Innego scenariusza upadku państwa dostarcza monarchia habsburska, której nigdy nie udało się osiągnąć stanu zbliżonego do państwa narodowego ${ }^{12}$. Monarchia Habsburgów, ukształtowana w dużym stopniu wskutek związków małżeńsko-dynastycznych i unijnych, od czasów późnego średniowiecza przez całą epokę nowożytną przypominała swoisty patchwork złożony nie tylko z wielu grup etnicznych, lecz także tworów państwowych o różnym stopniu suwerenności. We wczesnej epoce nowożytnej do habsburgische Erblande - oprócz dawnych „ziem dziedzicznych” związanych ze „starym” arcyksięstwem Austrii - zaczęto m.in. zaliczać również połączone po $1526 \mathrm{r}$. z panującą dynastią węzłem unii personalnej kraje Korony Czeskiej i Węgierskiej ${ }^{13}$, w których Habsburgowie odpowiednio w 1627 i 1717 r. uzyskali status władców dziedzicznych. Płynność granic, formowanie i zanik wchodzących w skład monarchii habsburskiej organizmów państwowych, quasi-państwowych i terytorialnych, stanowi fascynujący przykład nieustannej zmiany kształtów władztwa dynastycznego w długim trwaniu. Stąd też monarchia habsburska w historiografii zachodniej - niestety z kompletnie ahistorycznej perspektywy ${ }^{14}$ bywa charakteryzowana jako twór unikalny i tkwiąca w permanentnym kryzysie „polityczna anomalia”.

Mimo przekształcenia w 1867 r. w opartą na unii realnej cesarstwa Austrii i królestwa Węgier monarchię dualistyczną, rozpad wielonarodowego państwa Habsburgów po 1918 r. stanowi jeden z najbardziej spektakularnych na początku XX stulecia przypadków rozpadu państwowości. Rzecz przy tym znamienna, że upadek CK Austro-Węgier pozostawił po sobie w środkowo-wschodniej i południowej Europie kilka nowych państw narodowych, spośród których ustrojowo-formalnie tylko jedno, a mianowicie Królestwo Węgier, terytorialnie zredukowane traktatem pokojowym w Trianon w 1920 r., pozostało sukcesorem tradycji dynastycznych Habsburgów.

${ }_{11}$ Zob. Will Italy's Lombardy and Veneto follow Catalonia?, http://www.dw.com/en/ will-italys-lombardy-and-veneto-follow-catalonia/a-41047328 oraz E. Povoledo, First Scotland, Then Catalonia. And Now? Milan and Venice, „New York Times”, https://www.nytimes.com/2017/10/17/world/europe/italy-lombardy-veneto-referendum-autonomy. html (dostęp: 28 XI 2017).

12 Inaczej niż nowożytnej Hiszpanii czy nawet Wielkiej Brytanii z obowiązującym obecnie konstruktem sześciu rodzajów British nationality - zob. https://www.gov.uk/ types-of-british-nationality/overview (dostęp: 15 VIII 2017). Por. też analizę kwestii obywatelstwa państwowego we współczesnych państwach narodowych: D. Gosewinckel, Schutz und Freiheit? Staatsbürgerschaft in Europa im 20. und 21. Jahrhundert, Berlin 2016.

13 Oraz połączonego z Koroną Węgierską unią realną Królestwa Chorwacji.

14 Zob. Ch.W. Ingrao, The Habsburg Monarchy - 1618-1815, Cambridge 2000, s. 2 nn. 
Rozpad monarchii habsburskiej stanowi też ciekawy przykład kresu państwa typu imperialnego, które powstało dzięki upadkowi na początku XIX w. innego imperium o genezie i tradycjach sięgających wcześniejszych epok i odgrywającego w średniowiecznych i wczesnonowożytnych dziejach Europy rolę kluczową. Habsburgowie bowiem jako od 1804 r. dziedziczni cesarze Austrii, od schyłku średniowiecza aż do 1806 r., przez blisko 350 lat nieprzerwanie (wyjąwszy krótki epizod 1742-1745) zasiadali na elekcyjnym tronie Świętego Cesarstwa Rzymskiego - od schyłku XV w. nieformalnie, od XVII w. zaś oficjalnie nazywanego Świętym Cesarstwem Rzymskim Narodu Niemieckiego. Postrzegane już w XVII stuleciu jako monstrum, Święte Cesarstwo bywało porównywane przez niektórych współczesnych z Rzecząpospolitą ${ }^{15}$. Do dziś zresztą historycy zwracają uwagę na synchroniczność upadku na przełomie XVIII/XIX w. dawnej Rzeczypospolitej i „Starej Rzeszy” (Altes Reich) ${ }^{16}$. Tworzyła ona swoistą państwową superstrukturę, obejmującą ponad 200 mniejszych i większych świeckich i duchownych władztw terytorialnych oraz wolnych miast Rzeszy, pozostających między sobą w zmiennych konfiguracjach i interakcjach. Pandemiczny upadek lub zanik państw i władztw terytorialnych w Rzeszy, ich łączenie się i rozpad wskutek niestabilności czynnika monarchicznego (np. wskutek wymarcia książęcych dynastii czy polityki związków dynastyczno-małżeńskich) dostarcza wielu przykładów zarówno zaniku, jak też odradzania się państwowości w epoce średniowiecza i wczesnej nowożytności ${ }^{17}$.

W tym kontekście długiego trwania dawnej Rzeszy warto też zwrócić uwagę na kluczowe dla jej roli i znaczenia w Europie wyobrażenie ideologiczne - ideę sukcesji rzymskiej państwowości imperialnej. Koncepcja translatio imperii, korzeniami sięgająca do biblijnej wizji tzw. czterech imperiów (Dn 2,21), później zmodyfikowana przez św. Hieronima, otrzymała nową wykładnię wraz z „odnowieniem” Cesarstwa Rzymskiego przez koronację Karola Wielkiego w 800 r., a następnie powstaniem Cesarstwa Ottonów po 962 r. Podobnie jak w Europie Wschodniej wcześniej Bizancjum, a później państwo moskiewskie, średniowieczna i wczesnonowożytna idea chrześcijańskiego imperium nawiązywała do „przeniesienia” i kontynuacji imperium rzymskiego w postaci „drugiego”

${ }^{15}$ J. Woliński, Anonimowy traktat polityczny z XVII wieku, PH 50, 1959, 1, s. 87.

${ }_{16}$ Zob. ostatnio. H.-J. Bömelburg, E. Kizik, Altes Reich und Alte Republik. Deutsch-polnische Beziehungen und Verflechtungen 1500-1806, Darmstadt 2014 (Deutsch-polnische Geschichte), rozdz.: „Finis Poloniae und finis Germaniae”, s. 187-200.

17 I. Kąkolewski, Comparatio dwóch monstrów: Rzeczpospolita polsko-litewska a Rzesza Niemiecka w XVI-XVIII wieku, w: Rzeczpospolita - Europa. XVI-XVIII wiek. Próba konfrontacji, red. M. Kopczyński, W. Tygielski, Warszawa 1999, s. 143-162. 
i „trzeciego Rzymu”. Zresztą ideologiczne refleksy i odwołania do kontynuacji upadłej - przynajmniej wedle przyjętej powszechnie w nowożytnej historiografii i europejskiej kulturze pamięci chronologii - w $476 \mathrm{r}$. zachodniej części imperium rzymskiego były widoczne również w motywach ideowo-propagandowych towarzyszących imperialnym aspiracjom mocarstw zachodnioeuropejskich: szesnastowiecznej Hiszpanii, siedemnastowiecznej Francji i Anglii, a na początku XIX w. także w zdominowanej napoleońskim systemem Europie. W pewnym sensie dotyczy to też utworzonego w $1871 \mathrm{r}$. Cesarstwa Niemieckiego, bezpośrednio nawiązującego do idei sukcesji Świętego Cesarstwa Rzymskiego. Spośród wielu świadectw żywotności idei translatio imperii w kajzerowskich Niemczech na gruncie byłego zaboru pruskiego potwierdza ją ikonograficzny wystrój wnętrz kaplicy zamku cesarskiego w Poznaniu - ostatniej w Europie wzniesionej na potrzeby monarsze budowli o charakterze zamkowym, której budowę ukończono w 1910 r. ${ }^{18}$

Rzut oka na mapę polityczną Europy, zwłaszcza zaś środkowo-wschodniej i południowo-wschodniej części kontynentu, około roku 1000 i tysiąc lat później, pozwala prześledzić wiele epizodów upadku lub zaniku państwowości, zarazem zaś przykładów „odrodzenia” państw ${ }^{19}$. Nawet jeśli w tym ostatnim przypadku najczęściej chodziło nie o faktycznie „odrodzone”, co tylko tak właśnie stylizowane (i mitologizowane) na potrzeby bieżącej propagandy państwowej jakościowo zupełnie nowe państwa. Tak oto u schyłku XIX w. wskutek kryzysu, później zaś rozpadu w wyniku I wojny światowej imperium osmańskiego, a także habsburskiego i rosyjskiego, możliwe było powstanie w Europie Środkowo-Wschodniej i Południowo-Wschodniej wielu nowych państw, które

18 I. Kąkolewski, Miasto symboli. Poznań w epoce zaborów, w: Ziemia obiecana. Miasto i nowoczesność. Wystawa Muzeum Historii Polski, Warszawa 26 września - 6 grudnia 2015, red. E. Lewczuk, Warszawa 2015, s. 81-96.

${ }_{19}$ Przy tym na zmiany geopolityczne w historii Europy Środkowej i Południowo-Wschodniej w długim (millenialnym) trwaniu można również spojrzeć jako na quasi-kolonialną arenę ekspansji najpierw dwóch sukcesorów rzymskiej tradycji imperialnej (Bizancjum i Święte Cesarstwo Rzymskie), później zaś imperiów euroazjatyckich (imperium osmańskie i rosyjskie/sowieckie) konkurujących z organizmami typu imperialnego wywodzącymi się z konstrukcji Świętego Cesarstwa Rzymskiego Narodu Niemieckiego (Austro-Węgry, Cesarstwo Niemieckie). Na arenie tej również wieloetniczna Rzeczpospolita Obojga Narodów odgrywała w pewnym sensie rolę quasi-kolonialnego mocarstwa, które pod koniec XVII i na początku XVIII w. samo stało się ofiarą ekspansji imperiów sąsiednich. Por. najbardziej kompleksową do tej pory interpretację wczesnonowożytnej Rzeczypospolitej i jej dziedzictwa z perspektywy dyskursu postkolonialnego w inspirujących rozważaniach: J. Sowa, Fantomowe ciało króla. Peryferyjne zmagania z nowoczesna formą, Kraków 2011. 
w sferze polityki pamięci swych korzeni będą poszukiwać, nawiązując do tradycji średniowiecznych lub wczesnonowożytnych państwowości. Stąd też otwarte dla współczesnego polskiego lub litewskiego historyka pozostają kwestie „etnicznego przeniesienia” oraz społecznych wyobrażeń o kontynuacji „odrodzonych” po ponadwiekowych rozbiorach w $1918 \mathrm{r}$. państwowościach międzywojennej Polski i Litwy ${ }^{20}$.

Podobne ideologiczne zapotrzebowanie niosła ze sobą rekonstrukcja państw Europy Środkowo-Wschodniej w ramach tzw. bloku wschodniego po II wojnie światowej, która przyniosła kolejne „rozbiory i zabory”. Jedną z konsekwencji była nie tylko czteroletnia okupacja przez aliantów Niemiec od 1945 r., później zaś ich podział na dwa państwa, lecz także zgodnie interpretowana przez zwycięzców jako wyraz sprawiedliwości dziejowej i zapobieżenia dalszym groźbom „militaryzmu i reakcji" likwidacja państwowości Prus dekretem Alianckiej Komisji Kontroli z 25 lutego $1947 \mathrm{r}^{21}$

Z kolei przesunięcie zachodnich granic Polski opartych w 1945 r. na Odrze i Nysie ewokowało potrzebę stworzenia i upowszechnienia w Polsce Ludowej ideologemu „Ziem Odzyskanych”, nawiązującego do tradycji tzw. Polski piastowskiej. Tendencję tę wzmocniło podkreślanie tysiącletnich tradycji państwowości w ramach zakrojonych przez ekipę Władysława Gomułki na olbrzymią skalę obchodów Tysiąclecia Państwa Polskiego, wymierzonych przeciw kościelnym obchodom Milenium Chrztu Polski w 1966 r. $^{22}$ Podobnych nawiązań do mitologizowanych przez politykę historyczną państw socjalistycznych średniowiecznych (w przypadku zaś Rumunii nawet antycznych) korzeni ich „niepodległych” państwowości można przytoczyć więcej.

${ }^{20}$ Zob. na ten temat znakomite eseje: A. Nikžentaitis, Unie polsko-litewskie $w$ kulturach pamięci Litwy, w: Od Horodła do Horodła, s. 103-117 oraz idem, Zapomniany drugiLitwini w Rzeczypospolitej Obojga Narodów, w: Pod wspólnym niebem. Rzeczpospolita wielu narodów, wyznań i kultur. XVI-XVIII wiek. Wystawa Muzeum Historii Polski. Zamek Królewski w Warszawie 3 V- 31 VII 2012, red. nauk. I. Kąkolewski, M. Kopczyński, Warszawa 2012, s. 63-74; A. Bumblauskas, Konstytucja 3 maja a amnezja historyczna Litwy i Polski, w: ibidem, s. $75-85$.

${ }^{21}$ Zob. wstępne rozważania w S. Salmonowicz, Prusy. Dzieje państwa i społeczeństwa, Poznań 1987.

${ }^{22}$ Zob. ostatnio obszernie na ten temat B. Noszczak, „History as a tool in the state's struggle against the Catholic Church during the celebrations of the 'One-Thousand Years of the Polish State' (1956-1966/67)" (maszynopis); tekst ten ukaże się zbiorze artykułów: The Dawning of Christianity in Poland and across Central-Eastern Europe. History and the Politics of Memory w serii "Polish Studies - Transdisciplinary Perspectives” w wydawnictwie Peter Lang; zob. też idem, „Sacrum” czy „profanum”? Spór o istotę obchodów Milenium państwa polskiego (1949-1966), Warszawa 2002. 
Upadek sowieckiej supremacji po 1989 r. w państwach bloku wschodniego, które wybiły się na pełną suwerenność, potem zaś rozpad i transformacja imperialnych struktur wielonarodowego ZSRR oraz federacyjnej Jugosławii na początku lat dziewięćdziesiątych XX w. stworzyły nową koniunkturę w polityce historycznej na narodowo-heroizujące mity „odrodzenia” i „translacji państwowości” z odległych fragmentów dziejów ${ }^{23}$. Zarazem współczesnemu „odrodzeniu” państw w środkowo-wschodniej i wschodnio-południowej Europie ${ }^{24}$ towarzyszą w niektórych tzw. założycielskich zachodnich krajach Unii Europejskiej wspomniane wyżej dążenia do rekonstrukcji zanikłych wcześniej państwowości. Jednocześnie na procesy te nakłada się polityka integracyjna Unii, której konsekwencją jest dobrowolna redukcja suwerenności państw narodowych. Tendencja ta $\mathrm{z}$ jednej strony budzi reakcje odrzucenia w postaci fali „nowych” nacjonalizmów, z drugiej zaś potrzebę kreowania transnarodowej tożsamości kontynentalnej. Mimo że „republikańsko-demokratyczna" koncepcja jedności europejskiej jest zjawiskiem jakościowo nowym, również jej architekci oraz zorientowane paneuropejsko kręgi intelektualne z chęcią sięgają do mitologizujących odniesień w formule

${ }^{23}$ W odniesieniu do konkurencyjnie obchodzonego jubileuszu 1150 państwowości we współczesnej Rosji i Ukrainie zob. obszerną analizę: В.М. Ткаченко, Неподільна спадщина Давньої Русі (про святкування 1150-річчя зародження російської державності, „Проблеми всесвітньої історіï” 2016, 1, s. 24-49. Tekst ten ukaże się w języku angielskim w wymienionym wyżej w przyp. 22 zbiorze artykułów.

${ }^{24}$ Zarazem z globalnej perspektywy trzeba zwrócić uwagę, uwzględniając wszelkie różnice i konteksty przyczynowo-skutkowe, na czasową zbieżność procesów failed statehood oraz powstawania nowych państw w Europie Środkowo-Wschodniej i Wschodnio-Południowej na przełomie XX i XXI w. oraz podobnych procesów w niektórych regionach Afryki i Bliskiego Wschodu. W pewnym sensie procesy te można próbować sprowadzić do wspólnego mianownika: konsekwencji dekonstrukcji dominującego w danym regionie imperium lub stanu równowagi w stosunkach międzypaństwowych, a co za tym idzie „odrodzenia”/powstania nowych organizmów państwowych lub quasi-państwowych, które w trakcie trudnej transformacji często wchodzą w stan fragile state. Pytaniem pozostaje stopień fragility i szanse przetrwania nowych, z reguły nieuznawanych w pełni przez międzynarodową społeczność, nowych (proto)państwowości w Europie Wschodniej, powstałych w wyniku rozpadu struktur imperialnych i federacyjnych i zawdzięczających zalążki swej suwerenności wsparciu Federacji Rosyjskiej (np. Naddniestrzańska Republika Mołdawska) bądź Unii Europejskiej i USA (Kosowo). Podobne wątpliwości nasuwa trwałość takich failed states (a także sąsiadujących z nimi organizmów państwowych, które można zaklasyfikować do tej kategorii), jak w Afryce np. powstała w 1993 r. Erytrea czy w 2011 r. Sudan Południowy (mimo formalnego uznania tych państw przez społeczność międzynarodową), na Bliskim Wschodzie zaś protopaństwowe widmo Kurdystanu na terenach ogarniętych wojną domową Iraku i Syrii, dodatkowo w sytuacji anarchizacji wywołanej działaniami innego protopaństwowego organizmu - tzw. Państwa Islamskiego. 
translatio imperii. Przykładem tego w historiografii są poszukiwania prefiguracji Unii Europejskiej w Świętym Cesarstwie Rzymskim² ${ }^{25}$, a w polityce historycznej Międzynarodowa Nagroda Karola Wielkiego (niem. Karlspreis, od 1988 r. Internationaler Karlspreis zu Aachen) przyznawana w Niemczech od 1950 r. wybitnym osobistościom i instytucjom za zasługi w promowaniu pokoju i jedności w Europie.

Biogram: Igor Kąkolewski, dr. hab., profesor nadzwyczajny Uniwersytetu Warmińsko-Mazurskiego w Olsztynie; od 2014 r. pracuje jako zastępca dyrektora Centrum Badań Historycznych PAN w Berlinie. Obszar zainteresowań naukowych: historia Polski i Europy XVI-XVIII w. i stosunków polsko-niemieckich od schyłku średniowiecza do XX w., historia Żydów polskich i niemieckich we wczesnej epoce nowożytnej i XX w., badania kultur pamięci, muzealnictwo; kontakt: igor.kakolewski@cbh.pan.pl.

${ }^{25}$ Zob. m.in. G. Schmidt, Das Alte Reich und die Europäische Union - ein Versuch, w: Vorträge der Geisteswissenschaftlichen Klasse 2010-2011, red. M. Vielberg, Erfurt 2013, s. 79-98. 